\title{
In-situ isotope ratio measurement: a decade of development of applications for mantle peridotites and kimberlites
}

\author{
N.J. Pearson, W.L. Griffin, S.Y. O'Reilly \\ GEMOC Key Centre, Department of Earth and Planetary Sciences, Macquarie University, NSW 2109, Australia; \\ npearson@els.mq.edu.au
}

In the last decade the geochemistry and geochronology of kimberlites and mantle xenoliths has advanced dramatically through the precise in-situ measurement of trace element compositions and isotope ratios. This increased analytical capability is the product of coupling a laser-ablation microprobe (LAM) to an induced coupled plasma mass spectrometer (ICP-MS) and the rapid development of the multi-collector (MC-) ICP-MS. The higher precision of the MC-ICP-MS has enabled the development of in-situ high precision isotope ratio measurements for a range of geologically important isotopic systems (e.g. Rb-Sr, Nd-Sm, Lu-Hf, Re-Os). The impact of these advances is that the isotopic data can be used to place constraints on the timing of processes in the lithosphere and to better characterize the nature of these processes. In-situ analysis also allows the isotopic data to be interpreted within a microstructural context and the acquisition of multiple datasets (e.g. trace REE-Pb, PGE-Os, $\mathrm{Pb}-\mathrm{Hf}, \mathrm{Pb}-\mathrm{Os}$ ) on single grains or parts of grains.

The MC-ICPMS has been developed to a level where the typical within-run (internal) precision and between-run (external) precision for solution analyses are comparable to those for thermal ionization mass spectrometers (TIMS). The introduction of the secondgeneration sector-field MC-ICPMS brought a number of advantages over the quadrupole ICPMS, including simultaneous detection, flat-topped peaks and greater sensitivity. All of these factors contributed to the more precise measurement of isotope ratios that made the results from the MC-ICPMS directly comparable with those obtained by TIMS. The MC-ICPMS has two great advantages over TIMS: (1) due to the high efficiency of the ICP source to ionise refractory elements, the MC-ICPMS has become the instrument of choice to investigate mass-dependent isotopic fractionation of stable isotopes of light and heavy metals (e.g. $\mathrm{Li}, \mathrm{Mg}, \mathrm{Fe}, \mathrm{Cu}, \mathrm{Mo}, \mathrm{Tl}$ ); (2) a LAM system can be coupled to the MC-ICPMS for in situ high-precision microanalysis of isotopic ratios. This has led most notably to the combined $\mathrm{U}-\mathrm{Pb}$ and $\mathrm{Lu}-\mathrm{Hf}$ isotopic analysis of zircon (e.g. Griffin et al. 2000) as well as studies of a range of other radiogenic isotopic systems (e.g. Sr - Schmidberger et al., 2003, Neumann et al., 2004; Woodhead et al., 2005; Nd - Foster \& Vance, 2006, McFarlane \& McCulloch, 2007; Os -
Pearson et al., 2002, Alard et al. 2002, Aulbach et al., 2004).

There are many advantages to be gained by LAM-MC-ICPMS analysis, the most important being the potential information that can be obtained at the high spatial resolution. Like other microanalytical techniques laser ablation MC-ICPMS produces data that can be interpreted in a spatial context and integrated with microstructural and other geochemical datasets. Other advantages include the removal of the sample digestion and chemical purification procedures, high sample throughput, little or no memory and no solvent interferences. Despite the advances in recent years there remains a perception that the accuracy and precision of the in-situ measurements suffer in comparison to solution measurements because of matrix effects and isobaric interferences.

Many factors contribute to the accuracy and precision of in-situ measurements. These can be considered as the interplay between parameters related to the sample, the laser operating conditions and processes in the mass spectrometer. In the in-situ studies that have concentrated on radiogenic isotope systems the elements of interest are trace or minor elements in common rock-forming minerals (e.g. Sr in clinopyroxene, carbonate, feldspar, perovskite) or accessory phases (e.g. Hf in zircon, rutile; $\mathrm{Nd}$ in apatite, titanite; Os in mantle sulfide). The precision of an individual measurement is primarily a function of the number of ions counted and therefore depends on the concentration of the element in the mineral, the size of the laser pit, the sensitivity of the mass spectrometer and the counting time. In comparison with conventional solution analysis, the added complexity associated with the in-situ method primarily concerns the 'dirty' nature of the sample. This may cause matrix effects that can change instrumental mass fractionation and produce isotopic interferences (isobaric and other molecular overlaps) that also require procedures to correct mass bias. Isobaric interferences present a major problem in nearly all of the radiogenic isotopic systems of most interest: ${ }^{87} \mathrm{Rb}$ on ${ }^{87} \mathrm{Sr},{ }^{144} \mathrm{Sm}$ on ${ }^{144} \mathrm{Nd}$, ${ }^{176} \mathrm{Lu}$ and ${ }^{176} \mathrm{Yb}$ on ${ }^{176} \mathrm{Hf},{ }^{187} \mathrm{Re}$ on ${ }^{187} \mathrm{Os}$. As a consequence, precision is also dependent on the parentdaughter ratio in the mineral, as well as the absolute element abundances. 
The combination of the size of the mineral grain and the sensitivity of the mass spectrometer dictates the size of the laser pit (static hole or traverse) or whether multiple analyses can be undertaken to investigate zoning. In some cases the laser is used simply as a solid-sampling device in order to maximise the volume of material introduced in the mass spectrometer, thereby homogenising the sample but improving precision. The alternative approach is to use the laser as a microprobe to add isotopic data to internal variations identified using optical images or other geochemical data. This technique invariably involves using a smaller spot size with the consequent effect on precision. In deciding which approach to use it is worth considering that the first may give a very precise but geologically meaningless result if the sample is heterogeneous. This is also true for the comparison of data obtained by solution analysis of mineral separates and by LAM-MC-ICPMS.

The two most significant developments in LAM-MC-ICPMS in the past decade have been the analysis of Lu-Hf isotopes in zircon and Re-Os isotopes in sulfides and PGE alloys. Zircon and the sulfide minerals represent micro time capsules for the crust/mantle and mantle respectively, and the isotopic studies provide information about the evolution of each layer. By determining the timing of events in the crust and the underlying lithospheric mantle, linkages between crustal and mantle processes can be assessed and used to address key problems in geodynamics.

Zircon megacrysts represent a late stage in the crystallisation of the magmas that produced the low-Cr megacryst suite $(\mathrm{Ol}+\mathrm{Opx}+\mathrm{Cpx}+\mathrm{Gnt}+\mathrm{Ilm}+\mathrm{Phl}+\mathrm{Zir})$ found in many kimberlites. U-Pb dating of zircon in kimberlite has been widely performed on single- and multiple-collector instruments with accuracy and precision comparable to ion microprobe techniques (e.g. Belousova et al., 2001). More recently the method has been extended to the U-Pb systematics of rutile and perovskite (Batumike et al., 2008), with the latter providing a rapid, cost-effective method for dating eruption ages of kimberlites.

Griffin et al. (2000) were the first to demonstrate the significance of the isotopic composition of $\mathrm{Hf}$ in mantle-derived zircon megacrysts as an indicator of the sources of the parent magmas and the interaction of these magmas with the cratonic lithosphere. The study included zircons from African, Siberian and Australian kimberlites, with a range in age from $90 \mathrm{Ma}$ to $2500 \mathrm{Ma}$. Most of the zircons have $\varepsilon \mathrm{Hf}$ values between 0 and 10 , but values down to -16 were obtained. In plots of $\mathrm{Nd}-\mathrm{Hf}$ isotopes the Group I and Group II kimberlites define long trends pointing to low values below the terrestrial array. Combined with published $\mathrm{Nd}$ data on the silicate members of the low$\mathrm{Cr}$ megacryst suite, the $\mathrm{Hf}$ isotopic data indicate crystallisation of zircon from magmas also lying well below the terrestrial array. The depleted and metasomatised lherzolites and harzburgites that make up much of the Archean lithospheric mantle have $\mathrm{Lu} / \mathrm{Hf}$ ratios $(\leq 0.15)$, low enough to account for the lowest $\varepsilon H f$ observed in the zircons over time spans of
1-3.5 Ga. This led Griffin et al. (2000) to suggest that the magmas from which the kimberlitic zircons crystallised were derived from Depleted Mantle or OIB-type sources, and developed negative $\varepsilon \mathrm{Hf}$ through reaction with the subcontinental lithospheric mantle.

The development of in-situ techniques has also enabled the investigation of the scale of isotopic variation at the microscopic level. The significance of this capability is shown in a study of the origin of MARID xenoliths using in-situ analysis of Lu-Hf isotopes of rutile and zircon (Choukroun et al., 2005). The rutiles are isotopically very heterogeneous, both within and between grains, with an overall range in ${ }^{176} \mathrm{Hf} /{ }^{177} \mathrm{Hf}$ from $0.2812-0.2858$. The low Hf isotopic signatures indicate that the MARID rocks initially formed by interaction of asthenospheric melt with ancient $(3 \mathrm{Ga})$ harzburgitic mantle, which dominated their Hf budget. The range to high $\mathrm{Hf}$ isotopic signatures, well above the mean value for the presentday Depleted Mantle, was produced by later metasomatism by a fluid/melt with highly radiogenic Hf derived from the breakdown of eclogitic or peridotitic garnet. The low ${ }^{176} \mathrm{Hf} /{ }^{177} \mathrm{Hf}$ preserved in MARID rutiles also helps to resolve one of the minor controversies about the origin of kimberlites. The insitu rutile data, combined with published data on MARID rocks show that the Nd-Hf isotopic systematics of kimberlites and lamproites also can be explained by contamination of asthenospheric melts with the ancient subcontinental lithospheric mantle, without any hidden reservoirs.

A major advance in the application of Re-Os to mantle-derived rocks came with the recognition that the Os budget of such rocks is controlled by trace sulfide phases, and that these rocks typically contain multiple generations of sulfide with widely differing Os contents and Re/Os (Alard et al., 2000). In-situ ReOs isotope analysis of mantle sulfides has enabled the dating of depletion and metasomatism events in the lithospheric mantle and forced a reappraisal of the relevance of whole-rock measurements. GEMOC pioneered the development of LAM-MC-ICPMS techniques for the in-situ analysis of Os isotopes in individual sulfide grains and showed that different sulfide generations also have widely varying Re/Os and ${ }^{187} \mathrm{Os} /{ }^{188}$ Os (Pearson et al., 2002; Alard et al., 2002). The isotopic data indicate that there are multiple generations of sulfides in most mantle peridotites and whole-rock Re-Os ages thus reflect a mix of these different sulfide populations. In many samples the isotopic record preserved in enclosed residual primary sulfides gives older ages for original lithospheric mantle stabilization than obtained from the whole-rock data. Superimposed on this record is the poststabilisation history preserved in mainly interstitial sulfides. The implication is that whole-rock Os-isotope analyses of sulfide-bearing peridotites must represent mixtures of components with different ages and isotopic compositions. In such cases, the model ages of these rocks can only be regarded as minimum estimates of melt-depletion ages, and are unlikely to date any particular event (Griffin et al., 2004). 'Age' 
spectra for these mantle events commonly mirror temporal signatures for thermal and tectonic events in the overlying crust. The application of in-situ Re-Os analysis to mantle-derived xenoliths is demonstrating that much of the cratonic SCLM is older than previously thought, and that old SCLM is very persistent despite later tectonic reworking.

The in-situ isotopic techniques now available allow the integration of age information with other isotopic datasets to constrain the origin of a sample, but also to unravel the processes that have subsequently modified it. An example of this is the combined Pb-SrNd-Hf study of individual grains of LIMA (Lindsleyite-Mathiasite) minerals from the Jagersfontein kimberlite to constrain the timing of mantle metasomatism and the sources of the metasomatic material. The in-situ isotopic analyses show significant within-grain and inter-grain variability in $\mathrm{Sr}$ and $\mathrm{Pb}$ isotopic composition, less variation in $\mathrm{Nd}$ isotopic composition, and little variation in the isotopic composition of Hf. The LIMA phases are related to the Phlogopite-K-richterite-Peridotite (PKP) style of metasomatism and modeling of the $\mathrm{U}-\mathrm{Pb}$ isotopes gives a maximum age for this metasomatism at ca $180 \mathrm{Ma}$. The results suggest an interaction between a plumerelated fluid or melt with the isotopic characteristics of the "HIMU" reservoir, and a refertilised SCLM with relatively high ${ }^{87} \mathrm{Sr} /{ }^{86} \mathrm{Sr}$ but low ${ }^{206} \mathrm{~Pb} /{ }^{204} \mathrm{~Pb}$ and ${ }^{143} \mathrm{Nd} /{ }^{144} \mathrm{Nd}$, similar in many respects to the "EM1" component. This multi-isotope approach has recently been applied to the $\mathrm{U} / \mathrm{Pb}-\mathrm{Sr}-\mathrm{Nd}$ study of groundmass perovskite in kimberlites to assess the roles of contamination and alteration (see Donnelly et al., 9IKC-A-00125).

The impact of in situ isotope ratio analysis has advanced modern geochronology beyond the acquisition of dates. Not only does the method provide rapid and precise data, but it places these data in a micro-structural framework and allows integration with datasets produced by other micro-analytical techniques. The integration of these multiple sources of data is crucial in constraining the origin of the sample and the processes leading to its formation, so that we can understand the meaning of a date in terms of geological events. The development of these analytical techniques over recent years have made it possible to compare the large scale evolution of the crust and the history of its underlying mantle (O'Reilly et al., 2008). However this still remains possible only where xenolith-bearing volcanic rocks are available.

\section{References}

Alard, O., Griffin, W.L., Lorand, J.P., Jackson, S.E., O'Reilly, S.Y. 2000. Non-chondritic distribution of the highly siderophile elements in mantle sulfides. Nature 407, 891-894.

Alard, O., Griffin, W.L., Pearson, N.J., Lorand, J.-P., O'Reilly, S.Y. 2002. New insights into the Re-Os systematics of sub-continental lithospheric mantle from in situ analysis of sulphides. Earth \& Planetary Science Letters 203, 651-663.

Aulbach, S., Griffin, W.L., Pearson, N.J., O'Reilly, S.Y., Kivi, K., Doyle, B.J. 2004. Mantle formation and evolution, Slave Craton: constraints from HSE abundances and Re-Os isotope systematics of sulfide inclusions in mantle xenocrysts. Chemical Geology 208, 61-88.

Batumike, J.M. Griffin, W.L., Belousova, E.A., Pearson, N.J., O'Reilly, S.Y., Shee, S. 2008. LAM-ICPMSU-Pb dating of kimberlitic perovskite: Eocene-Oligocene Kimberlites from the Kundelungu Plateau, D.R. Congo. Earth \& Planetary Science Letters 267, 609-619.

Belousova, E.A., Griffin, W.L., Shee, S.R., Jackson, S.E., O'Reilly, S.Y. 2001. Two age populations of zircons from the Timber Creek kimberlites, Northern Territory, Australia, as determined by laser-ablation ICPMS analysis. Australian Journal of Earth Sciences 48, 757766.

Choukroun, M., O'Reilly, S.Y., Griffin, W.L., Pearson, N.J., Dawson, J.B. 2005. Hf isotopes of MARID (micaamphibole-rutile-ilmenite-diopside) rutile trace metasomatic processes in the lithospheric mantle. Geology 33, 45-48.

Foster, G.L., Vance, D, 2006. In situ Nd isotopic analysis of geological materials by MC-ICP-MS. Journal of Analytical Atomic Spectrometry 21, 288-296.

Griffin, W.L., Pearson, N.J., Belousova, E., Jackson, S.E., van Achterbergh, E., O'Reilly, S.Y., Shee, S.R. 2000. The Hf isotope composition of cratonic mantle: LAMMC-ICPMS analysis of zircon megacrysts in kimberlites. Geochimica et Cosmochimica Acta 64, 133-147.

Griffin, W.L., Graham, S., O'Reilly, S.Y., Pearson, N.J. 2004. Lithospheric evolution beneath the Kaapvaal Craton: Re-Os systematics of sulfides in mantle-derived peridotites. Chemical Geology 208, 89-118.

McFarlane, C.R.M., McCulloch, M.T., 2007. Coupling of insitu Nd-Sm systematics and $\mathrm{U}-\mathrm{Pb}$ dating of monazite and allanite with application to crustal evolution studies. Chemical Geology 245, 45-60.

Neumann, E., Griffin, W.L., Pearson, N.J., O'Reilly, S.Y. 2004. The evolution of the upper mantle beneath the Canary Islands: Information from trace elements and $\mathrm{Sr}$ isotope ratios in minerals in mantle xenoliths. Journal of Petrology 45, 2573-2612.

O'Reilly, S.Y., Griffin, W.L., Pearson, N.J., Jackson, S.E., Belousova, E.A., Alard, O., Saeed, A., 2008. Taking the pulse of the Earth: linking crustal and mantle events. Australian Journal of Earth Sciences. In press.

Pearson, N.J., Alard, O., Griffin, W.L., Jackson, S.E., O'Reilly, S.Y. 2002. In situ measurement of Re-Os isotopes in mantle sulfides by laser ablation multicollector-inductively coupled plasma mass spectrometry: Analytical methods and preliminary results. Geochimica et Cosmochimica Acta 66, 10371050 .

Schmidberger, S.S., Simonetti, A., Francis, D., 2003. Smallscale $\mathrm{Sr}$ isotope investigation of clinopyroxenes from peridotite xenoliths by laser ablation-MC-ICP-MS implications for mantle metasomatism Chemical Geology 199, 317-329.

Woodhead, J.D., Swearer, S., Hergt, J., Maas, R., 2005. In situ Sr-isotope analysis of carbonates by LA-MC-ICPMS: interference corrections, high spatial resolution and an example from otolith studies. Journal of Analytical Atomic Spectrometry 20, 22-27. 